\author{
Branislav Jovanović ${ }^{1}$ \\ Miloš Maljković ${ }^{2}$ \\ Dragan Stamenković ${ }^{3}$ \\ Vladimir Popović 4
}

JEL: R49

DOI: $10.5937 /$ industrija49-31337

UDC:

Original Scientific Paper

\title{
Fuel savings by using better-quality insulation in refrigerated vans ${ }^{5}$
}

\author{
Article history: \\ Received: 15 January 2021 \\ Sent for revision: 2 April 2021 \\ Received in revised form: 17 April 2021 \\ Accepted: 19 April 2021 \\ Available online: 30 April 2021
}

\begin{abstract}
An additional attention must be payed to the energy efficiency of refrigerated vans transporting perishable foodstuffs, because inefficient operation of refrigeration units installed on these vehicles increases fuel consumption and exhaust gases emissions. The amount of fuel consumed by mechanical refrigeration unit drive can be reduced in many ways. This paper is analysing the impact of thermal insulation quality on the fuel consumed by mechanical refrigeration unit installed on a typical van. The results of the research show that by choosing better-quality thermal insulation around $€ 420$ can be saved annually on fuel consumed by mechanical refrigeration unit driven by vehicle's engine while transporting deeply frozen fish at $-20{ }^{\circ} \mathrm{C}$ (or other foodstuffs at given temperature). If the van is transporting raw meat (for example) at $0^{\circ} \mathrm{C}$ annual savings can be around $€ 110$. When the van is used for transport of deeply frozen fish the investment will pay off after 3.5 years of vehicle exploitation, while if the raw meat is transported the investment will pay off after approximately 14 years. The analysis includes the price of insulating
\end{abstract}

\footnotetext{
${ }^{1}$ University of Belgrade, Faculty of Mechanical Engineering, bjovanovic@mas.bg.ac.rs 2 University of Belgrade, Faculty of Mechanical Engineering

${ }^{3}$ University of Belgrade, Faculty of Mechanical Engineering

${ }^{4}$ University of Belgrade, Faculty of Mechanical Engineering

${ }^{5}$ The research presented in this paper is funded by the Ministry of Education, Science and Technological Development of the Republic of Serbia under agreement No. 45103-9/2021-14/200105.
}

Industrija, Vol.49, No.1, 2021 
the van, current fuel price in Serbia, as well as the average monthly temperatures in the territory of Belgrade, Serbia.

Keywords: refrigerated vans, mechanical refrigeration unit, fuel consumption, fuel economy, thermal insulation

\section{Ušteda u potrošnji goriva ostvarena upotrebom pojačane termoizolacije tovarnog prostora dostavnih vozila}

Apstrakt: Energetskoj efikasnosti dostavnih vozila koja prevoze lakokvarljive namirnice se mora posvetiti dodatna pažnja jer neefikasan rad mehaničkih rashladnih uređaja ugrađenih na ovakva vozila dovodi do povećanja potrošnje goriva i emisije izduvnih gasova. Količina goriva utrošena za pogon rashladnog uređaja može biti smanjena na više načina. Ovaj rad se bavi analizom uticaja kvaliteta termoizolacije na potrošnju goriva za pogon rashladnog uređaja ugrađenog na uobičajeno dostavno vozilo. Rezultati analize pokazuju da se izborom pojačane termoizolacije troškovi goriva za pogon rashladnog uređaja mogu smanjiti za oko $420 €$ godišnje, ukoliko se prevozi duboko smrznuta riba na zadatoj temperaturi od $-20{ }^{\circ} \mathrm{C}$ (ili drugi prehrambeni proizvodi na istoj temperaturi), dok je ušteda pri prevozu svežeg mesa (na primer) na $0{ }^{\circ} \mathrm{C}$ oko $110 €$ godišnje. Kada se dostavno vozilo koristi za transport duboko smrznute ribe ulaganje će se isplatiti nakon eksploatacije vozila od 3.5 godine, ali ako se vozilo koristi za prevoz svežeg mesa ulaganje će se isplatiti nakon oko 14 godina. $U$ analizu je uključena cena ugradnje termoizolacije, trenutna cena goriva u Srbiji, kao i prosečne mesečne temperature na teritoriji Beograda.

Ključne reči: rashladna vozila, mehanički rashladni uređaj, potrošnja goriva, ekonomičnost, termoizolacija

\section{Introduction}

The ATP agreement is an international agreement on the transport of perishable foodstuffs that also defines special conditions under which those foodstuffs are transported. The transport of perishable foodstuffs on the territory of Serbia is usually performed by road vehicles (vans, trucks, trailers and semitrailers). The basic classification of these road vehicles is based on the quality of insulation, hence there is normally insulated and heavily insulated equipment. The quality of insulation is expressed through the overall coefficient of heat transfer. 
Insulated equipment fitted with its own refrigerating appliance is classified as mechanically refrigerated. The usual principle of operation of these refrigeration units is based on a mechanical compressor which can be powered by the vehicle engine, or with the help of internal combustion engine which is a part of the independent refrigeration unit (usually found on trucks, trailers and semitrailers).

Today, there are about 4 million refrigerated vehicles in use worldwide, with about $40 \%$ share of small trucks and vans with cargo volume not exceeding 19 $\mathrm{m}^{3}$ as stated by Glouannec, Michel, Delamarre \& Grohens (2014). They also showed that the usage of advanced insulating materials decreases the impact of solar irradiation on heat transfer through insulation of vans by $27 \%$.

Zakharov, Magaril \& Kozlov (2017) analysed the efficiency of refrigerated vehicles in summer conditions while operating on urban routes. They emphasised that the impact of number of times the doors of the van are opened while delivering foodstuffs is highly influential on energy consumed by refrigeration units, and recommended optimal loading of the vehicle during exploitation. Also, they proposed replacement of mechanical refrigeration units with eutectic plates for certain type of routes and weather conditions.

Estrada-Flores \& Eddy (2006) also evaluated the impact of temperature variation induced by number of times the doors of the van are opened on thermal insulation and mechanical refrigeration unit's effectiveness. Testing was done on five refrigerated vans. They concluded that performance of vans is highly dependent on door opening management.

Tassou, De-Lille \& Ge (2008) proposed the use of thermal energy storage such as eutectic plates instead of mechanical refrigeration unit for short routes.

\section{Aims of research}

One of the goals of this research is to show how much fuel can be saved during exploitation of a van equipped with mechanical refrigeration unit and thermal insulation of the cargo compartment that meets the requirements of the ATP agreement (better-quality insulation), compared to the same vehicle with the cargo compartment insulated with a material that has inadequate thermal insulation properties and which is not in accordance with ATP agreement (the overall coefficient of heat transfer higher than 0.7 ).

Typical van (Figure 1) is used as a reference, while the analysis is performed for thermal insulation that provides an overall coefficient of heat transfer of 0.5 $\mathrm{W} / \mathrm{m}^{2} \mathrm{~K}$ (according to the requirements of the ATP agreement) and insulation 
that provides an overall coefficient of heat transfer of $0.9 \mathrm{~W} / \mathrm{m}^{2} \mathrm{~K}$ (not in accordance with the requirements of the ATP agreement). The values of the stated heat transfer coefficients are approximated on the basis of tests performed on various typical vans.

In addition to the values of the overall coefficient of heat transfer provided, aforementioned types of insulation also differ in price. Based on information obtained from the bodybuilders, the price of better-quality thermal insulation for the considered vehicle is $€ 3500$, while the price of insulation with a material that has inadequate thermal insulation properties is $€ 2000$. The aim of this research is also to show for how much the investment in better-quality thermal insulation pays off in terms of reduced fuel consumption for the mechanical refrigeration unit drive.

Figure 1. Typical refrigerated van

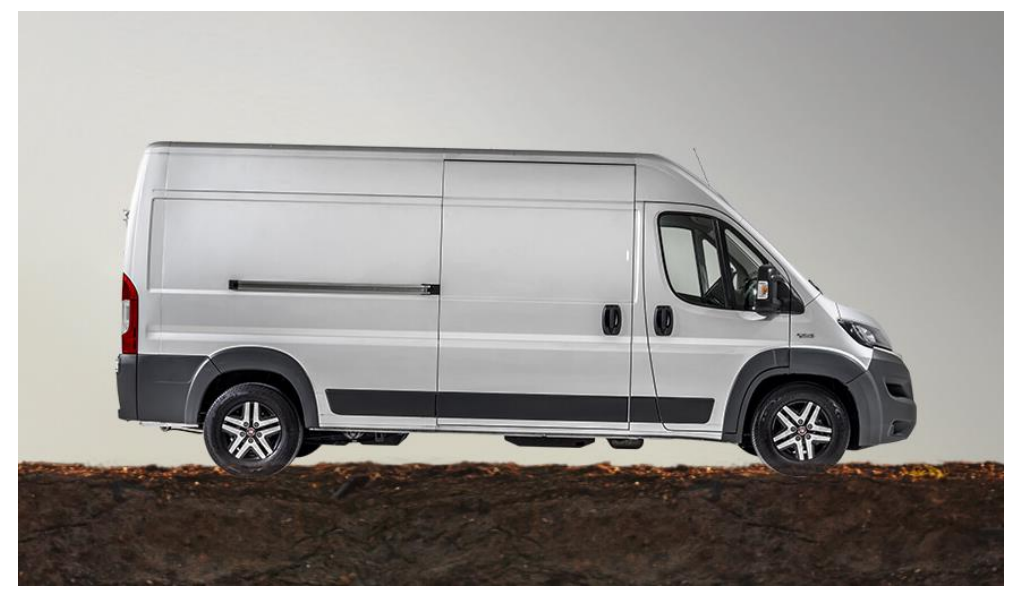

Source: $h$ ttps://www.fiatprofessional.com/ducato/van

\section{Research methodology}

The analysis is performed for two cases - transport of deep-frozen fish and raw meat. Therefore, for the transport of deep-frozen fish, it is necessary to provide a temperature of $-20^{\circ} \mathrm{C}$ inside the cargo compartment, while for raw meat it is necessary to provide $0^{\circ} \mathrm{C}$. Refrigerated vans are also used for transportation of pasteurized milk and fresh dairy products $\left(+6^{\circ} \mathrm{C}\right)$, processed meat products $\left(+4{ }^{\circ} \mathrm{C}\right.$ ) and baked goods (from $0{ }^{\circ} \mathrm{C}$ to $+4^{\circ} \mathrm{C}$ ). As stated before, the specific 
characteristic of the refrigerated vans is that the compressor of the mechanical refrigeration unit is driven by the vehicle engine. Therefore, it is necessary to determine the amount of fuel that the vehicle engine consumes to drive the compressor, bearing in mind that the refrigerated van must be capable of maintaining the set temperature throughout the whole transport route, regardless if the vehicle is in motion, if it is stationary or the engine is off (Jovanović, Popović, \& Stamenković, 2018).

The important thing for the analysis is the difference between the desired temperature in the cargo compartment and the ambient temperature. For this purpose, based on weather reports on the mean monthly temperature (collected during 2005-2015) in the city of Belgrade, Serbia (Figure 2) (Time and date AS, 2020), the stated temperature difference is determined.

Figure 2. Mean monthly temperature in city of Belgrade, Serbia (2005-2015.)

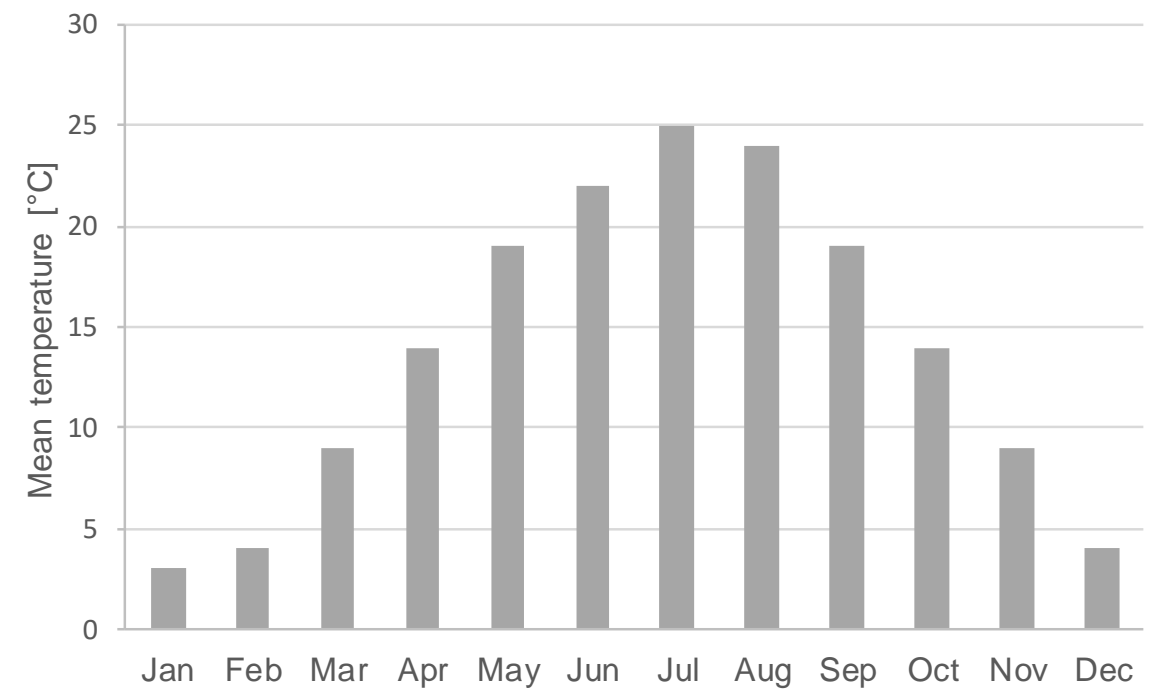

This has a significant impact (besides the quality of thermal insulation) on the operating time of the refrigeration unit - a parameter that affects the fuel consumption. For example, the difference between the desired cargo compartment temperature and mean ambient temperature in the first quarter of the year is $25.3^{\circ} \mathrm{C}$ and $5.3{ }^{\circ} \mathrm{C}$, for the deep-frozen fish and raw meat, respectively. 
In order to determine heat losses, the overall coefficient of heat transfer, the mean surface area of the cargo compartment and the difference between the desired temperature inside the cargo compartment and the ambient temperature must be known.

Thus, heat losses are calculated based on the following equation:

where:

$$
Q=K \cdot S \cdot \Delta T,
$$

$K$ is the overall coefficient of heat transfer $\left[\mathrm{W} / \mathrm{m}^{2} \mathrm{~K}\right]$;

$S$ is the mean surface area of cargo compartment [ $\left.\mathrm{m}^{2}\right]$;

$\Delta T$ is the difference between the desired temperature inside the cargo compartment and the ambient temperature $[\mathrm{K}]$.

The vehicle considered in this research is characterised by the mean surface area of the cargo compartment of $32 \mathrm{~m}^{2}$, while the parameter $\Delta T$ is determined for each of the foodstuffs transported and different ambient temperatures.

The required operating time of the refrigeration unit (expressed in \%) is then determined as the ratio of heat losses $Q$ and the effective refrigerating capacity of the refrigeration unit at the temperature needed for transport of perishable foodstuffs (in our case $-20^{\circ} \mathrm{C}$ or $0^{\circ} \mathrm{C}$ ).

Typical mechanical refrigeration unit is chosen (unit intended for vans with cargo compartment volume not exceeding $\left.17 \mathrm{~m}^{3}\right)$, characterised by the effective refrigerating capacities of $1840 \mathrm{~W}\left(P_{-20}\right)$ and $3330 \mathrm{~W}\left(P_{0}\right)$ at $-20{ }^{\circ} \mathrm{C}$ and $0^{\circ} \mathrm{C}$, respectively.

It is assumed that the vehicle operates for 8 hours a day during 250 working days per year, which is taken into account for the calculation of the required operating time of the refrigeration unit throughout the year.

In order to determine the amount of fuel that the vehicle engine consumes to drive the compressor of the mechanical refrigeration unit, the approximated specific fuel consumption of the diesel engine $c_{s}=165 \mathrm{~g} / \mathrm{kWh}$ is used, which is considered standard for modern diesel engines (Government of the Czech Republic, 2008). Also, based on well-known data, the density of diesel fuel of $836 \mathrm{~kg} / \mathrm{m}^{3}$ is taken into account.

The alternator of the vehicle should provide an additional power of $420 \mathrm{~W}$ (value approximated based on the data available from the test reports of different mechanical refrigeration units issued by competent authorities on the request of units' manufacturers) to drive the fans, so this is also necessary to take into account when calculating the amount of fuel consumed. Also, it is necessary to 86 
include the efficiency of the alternator that is considered to be about $50 \%$ (Government of the Czech Republic, 2008).

Based on the data available from the above mentioned test reports of different mechanical refrigeration units, the efficiency of the mechanical refrigeration unit is approximated by taking into account the ratio of consumed energy (input) to the effective refrigerating capacity (output). So, for the effective refrigerating capacity of $1840 \mathrm{~W}\left(-20^{\circ} \mathrm{C}\right)$ the efficiency is approximated as $67 \%$, while for the effective refrigerating capacity of $3330 \mathrm{~W}\left(0^{\circ} \mathrm{C}\right)$ the efficiency is approximated as $97 \%$.

So, the power needed to drive the compressor is determined by the following equations, for the desired temperatures inside the cargo compartment of -20 ${ }^{\circ} \mathrm{C}$ and $0{ }^{\circ} \mathrm{C}$, respectively.

$$
\begin{gathered}
P_{\text {comp-20 }}=\frac{P_{-20}}{0.67}, \\
P_{\text {comp } 0}=\frac{P_{0}}{0.97},
\end{gathered}
$$

where:

$P_{\text {comp-20 }}$ and $P_{\text {compo }}$ are values of power consumed to drive the compressor for the desired temperatures inside the cargo compartment of $-20^{\circ} \mathrm{C}$ and $0{ }^{\circ} \mathrm{C}$, respectively [W];

$P_{-20}$ and $P_{0}$ are the effective refrigerating capacities for the desired temperatures inside the cargo compartment of $-20^{\circ} \mathrm{C}$ and $0{ }^{\circ} \mathrm{C}$, respectively $[\mathrm{W}]$.

The power generated by the engine to drive the compressor and fans of the mechanical refrigeration unit for the set temperatures of $-20^{\circ} \mathrm{C}$ and $0{ }^{\circ} \mathrm{C}$ is determined using the following equations:

$$
\begin{gathered}
P_{\text {eng-20 }}=P_{\text {comp }-20}+2 \cdot P_{f}, \\
P_{\text {eng } 0}=P_{\text {comp } 0}+2 \cdot P_{f},
\end{gathered}
$$

where:

$P_{\text {eng-20 }}$ and $P_{\text {engo }}$ are values of power generated by the engine to drive the compressor for the desired temperatures inside the cargo compartment of -20 ${ }^{\circ} \mathrm{C}$ and $0{ }^{\circ} \mathrm{C}$, respectively [W];

$P_{f}$ is power generated by the engine to drive fans (multiplied by 2 to account for the efficiency of alternator) [W]. 
Then the fuel consumption of the mechanical refrigeration unit can be obtained according to the following equations:

$$
\begin{gathered}
c_{f-20}=P_{\text {eng-20}} \cdot c_{s}, \\
c_{f 0}=P_{\text {eng } 0} \cdot c_{s},
\end{gathered}
$$

where:

$c_{t-20}$ and $c_{f o}$ represent fuel consumption of the mechanical refrigeration unit for the desired temperatures inside the cargo compartment of $-20^{\circ} \mathrm{C}$ and $0{ }^{\circ} \mathrm{C}$, respectively $[\mathrm{g} / \mathrm{h}]$;

$C_{s}$ is approximated specific fuel consumption of the diesel engine $[\mathrm{g} / \mathrm{kWh}]$.

The fuel consumption can be expressed in litres per hour (by dividing the equations (6) and (7) by the density of diesel fuel), and thus determine the amount of fuel consumed in litres (number of operating hours of the mechanical refrigeration unit was calculated earlier).

\section{Results and discussion}

The results obtained on the basis of the calculations described in the previous chapter are given in Table 1 for deeply frozen fish and raw meat. It can be seen that when transporting deep-frozen fish, the cost of fuel ( $€ 1.25$ - current price per litre of diesel fuel in Serbia) spent on refrigeration unit drive will be $€ 518$ for a vehicle with thermal insulation that provides the overall coefficient of heat transfer of about $0.5 \mathrm{~W} / \mathrm{m}^{2} \mathrm{~K}$, while these costs for vehicle with insulation that provides the overall coefficient of heat transfer of about $0.9 \mathrm{~W} / \mathrm{m}^{2} \mathrm{~K}$ are significantly higher and amount about $€ 932$.

Table 1. Calculation results

\begin{tabular}{|c|c|c|c|c|}
\hline $\begin{array}{c}\text { The overall heat transfer coefficient } \\
{\left[\mathrm{W} / \mathrm{m}^{2} \mathrm{~K}\right]}\end{array}$ & \multicolumn{2}{|c|}{0.5} & \multicolumn{2}{c|}{0.9} \\
\hline Type of goods & $\begin{array}{c}\text { Deeply } \\
\text { frozen } \\
\text { fish }\end{array}$ & $\begin{array}{c}\text { Raw } \\
\text { meat }\end{array}$ & $\begin{array}{c}\text { Deeply } \\
\text { frozen } \\
\text { fish }\end{array}$ & $\begin{array}{c}\text { Raw } \\
\text { meat }\end{array}$ \\
\hline Annual refrigeration unit operating time [h] & 546 & 131 & 982 & 237 \\
\hline $\begin{array}{c}\text { Annual amount of fuel consumed for } \\
\text { refrigeration unit drive [l] }\end{array}$ & 413 & 111 & 744 & 199 \\
\hline $\begin{array}{c}\text { Annual cost of fuel consumed for } \\
\text { refrigeration unit drive }[€]\end{array}$ & 518 & 139 & 932 & 250 \\
\hline
\end{tabular}

88 
In the first case $\left(K \approx 0.5 \mathrm{~W} / \mathrm{m}^{2} \mathrm{~K}\right)$, the mechanical refrigeration unit should operate 546 hours per year, so this leads to 413 litres of fuel consumed annually for the refrigeration unit operation. In the second considered case $(K \approx 0.9$ $\mathrm{W} / \mathrm{m}^{2} \mathrm{~K}$ ), the refrigeration unit should operate for as much as 982 hours per year, which leads to 744 litres of fuel consumed.

When transporting raw meat, the annual fuel costs for the operation of the refrigeration unit is $€ 139\left(K \approx 0.5 \mathrm{~W} / \mathrm{m}^{2} \mathrm{~K}\right)$, while in the second case considered $\left(K \approx 0.9 \mathrm{~W} / \mathrm{m}^{2} \mathrm{~K}\right)$ these costs are about $€ 250$.

So, in the first case $\left(K \approx 0.5 \mathrm{~W} / \mathrm{m}^{2} \mathrm{~K}\right)$ the operating time of the mechanical refrigeration unit is about 131 hours per year, which corresponds to a fuel consumption of 111 litres per year. In the second case $\left(K \approx 0.9 \mathrm{~W} / \mathrm{m}^{2} \mathrm{~K}\right)$, the refrigeration unit should operate for 237 hours per year, which leads to 199 litres of fuel consumed to drive the refrigeration unit.

The total costs during the first year of operation and transportation of deepfrozen fish (fuel for refrigeration unit drive and the cost of thermal insulation) will be $€ 4018$ if better-quality thermal insulation is used, while insulating the cargo compartment with a material which has inadequate thermal properties leads to a total cost of $€ 2932$.

Also, the total costs during the first year of exploitation and transportation of raw meat will be $€ 3639$ if better-quality thermal insulation is used, while the usage of inadequate insulation material leads to a total cost of $€ 2250$.

\section{Conclusion}

The results of the performed calculations show that by choosing better-quality thermal insulation about $€ 420$ annually can be saved on fuel consumed by mechanical refrigeration unit while transporting deeply-frozen fish at $-20^{\circ} \mathrm{C}$. If the van is transporting raw meat at $0^{\circ} \mathrm{C}$ annual savings can be about $€ 110$.

It can be seen that the investment in better-quality thermal insulation for transportation of deeply frozen fish will pay off after 3.5 years of vehicle exploitation, while if the vehicle is transporting raw meat the investment will pay off after approximately 14 years.

So, it can be said that the investment in better-quality thermal insulation will pay off earlier if the vehicle transports deeply frozen fish or other types of deepfrozen foodstuffs instead of the raw meat, by keeping in mind that a time period of 14 years can exceed the operating life cycle of the vehicle. 
Certain savings can be made in regard to refrigeration unit maintenance costs, because better-quality thermal insulation reduces annual operating time of refrigeration unit. Number of door openings during loading or unloading of the van and the vehicle mass increase due to the thermal insulation installation can additionally increase fuel consumption. Also, driver's behaviour in regard to gear selection can have a great influence on the total energy efficiency of refrigerated vans, mainly because they operate in urban traffic conditions (Blagojević et al., 2013). These facts can also be taken into account in future research. High number of door openings can also prevent the achievement of desired temperature inside the cargo compartment in vans with inadequate quality of thermal insulation.

There are also other benefits of better-quality thermal insulation - reduced exhaust gases emissions due to shorter operating time of the refrigeration unit and consequently less fuel used. For example, during transportation of deeply frozen fish, about 331 litres of diesel fuel is saved annually.

Taking into account that 1 litre of burned diesel fuel emits $2.66 \mathrm{~kg} \mathrm{CO}_{2}$ (Natural Resources Canada, 2014) into atmosphere, in this case the vehicle annually emits about $880 \mathrm{~kg} \mathrm{CO}$ less. Also, because vans are powered by diesel engines, emissions of $\mathrm{CO}$ are negligible, but NOx emissions can be significant and are around $18 \%$ higher in refrigerated vans than in standard vans (without refrigeration units) (Yang et al., 2020). This must be taken into account when opting for better-quality insulation, because inadequate thermal insulation will additionally increase these emissions due to higher amount of fuel consumed by refrigerated van.

Vehicle engine speed has an influence on the refrigeration unit performance and the effects of oscillations of engine speed on the refrigeration unit drive should also be considered in future research.

Based on the conclusions given in this research, authors recommend the mandatory certification according to the ATP agreement of this type of vehicles registered in the Republic of Serbia. This will ensure safe transport of perishable foodstuffs and reduce pollution in urban areas, where these vehicles mainly operate.

\section{Acknowledgments}

The research presented in this paper is funded by the Ministry of Education, Science and Technological Development of the Republic of Serbia under agreement No. 451-03-9/2021-14/200105. 


\section{References}

Blagojević, I., Vorotović, G., Ivanović, G., Janković, S. \& Popović, V. (2013). Energy efficiency improvement by gear shifting optimization. Thermal Science, 17(1), 99105. doi.org/10.2298/TSCl120129035B

Estrada-Flores, S., \& Eddy, A. (2006). Thermal performance indicators for refrigerated road vehicles. International Journal of Refrigeration, 29(6), 889-898. doi.org/10.1016/j.jijrefrig.2006.01.012

Glouannec, P., Michel, B., Delamarre, G., \& Grohens, Y. (2014). Experimental and numerical study of heat transfer across insulation wall of a refrigerated integral panel van. Applied Thermal Engineering, 73(1), 196-206. doi.org/10.1016/j.applthermaleng.2014.07.044

Government of the Czech Republic. (2008). Fuel consumption measurement method for vehicle-powered refrigeration units based on the concept of a standard vehicle engine / transmitted by the Government of the Czech Republic. Retrieved from https://digitallibrary.un.org/record/633866

Jovanović, B., Popović, V., Stamenković, D. (2018, May). Good distribution practice requirements for vehicles intended for transport of time and temperature sensitive pharmaceutical products. Paper presented at the Maintenance Forum 2018, Belgrade. Retrieved from http://www.maintenanceforum.net/cp2018/papers/8588\%20B_Jovanovic.pdf

National Resources Canada. (2014). Learn the facts: Fuel consumption and $\mathrm{CO}_{2}$ Retrieved from https://www.nrcan.gc.ca/sites/www.nrcan.gc.ca/files/oee/pdf/ transportation/fuel-efficient-technologies/autosmart_factsheet_6_e.pdf

Tassou, S.A., De-Lille, G., Ge, Y.T. (2009). Food transport refrigeration - Approaches to reduce energy consumption and environmental impacts of road transport. Applied Thermal Engineering, 29(8-9), 1467-1477. doi.org/10.1016/j.applthermaleng. 2008.06.027

Time and Date AS. (2020). Annual Weather Averages in Belgrade 2005-2015. Retrieved from https://www.timeanddate.com/weather/serbia/belgrade/climate

Yang, Z., Tate, J., Morganti, E., Shepherd, S. (2021). Real-world $\mathrm{CO}_{2}$ and $\mathrm{NO}_{\mathrm{x}}$ emissions from refrigerated vans. Science of the Total Environment, 763. doi.org/10.1016/j.scitotenv.2020.142974

Zakharov, D., Magaril, E., \& Kozlov, P. (2017). Reducing the energy consumption and increasing the efficiency of perishable goods transportation by refrigerated vehicles on urban routes. International Journal of Sustainable Development and Planning, 12(7), 1192-1202. doi.org/10.2495/SDP-V12-N7-1192-1202 